\title{
Laços que prendem: interpretações culturais sobre a maturidade tardia na Europa ocidental e no Japão*
}

\author{
Katherine S. Newman **
}

\section{Resumo}

Nas sociedades nas quais a "saída tardia" da casa da família é comum, as pressões estruturais que levam nessa direção são semelhantes. No entanto, a resposta cultural varia consideravelmente de uma sociedade para outra. A análise comparativa entre vários países sugere que fatores demográficos muito semelhantes assumem um grau diferente de significação e distintos padrões de sentido. De fato, o que há de mais comum entre os países a respeito da saída tardia de casa, são as respostas políticas de seus governos, uniformemente preocupados com o declínio da taxa de nascimentos. Quanto aos cidadãos comuns, o "fracasso em começar" varia de uma catástrofe social (Japão), passando por uma frustração estrutural mais leve (Espanha) até a não problematização, ao passo que para seus pares nórdicos, a capacidade de começar cedo é enfrentada sem hesitação, mas acompanhada pela aborrecida sensação de que as gerações não precisam tanto uma da outra como de fato deveriam precisar.

Palavras-chave: Saída Tardia da Casa da Família, Japão, Espanha, Países Nórdicos.

\footnotetext{
* Recebido para publicação em abril de 2009, aceito em maio de 2009. Adaptado do Discurso Presidencial de Katherine Newman na Easten Sociological Society, 22 de fevereiro de 2008. O apoio para este projeto veio do fundo de pesquisa docente da Woodrow Wilson School; o European University Institute abrigou minha equipe de pesquisa em nossas sessões de treinamento. As análises apresentadas nos quadros foram compiladas por Sofya Aptekar e antes publicadas em nosso trabalho conjunto (Newman e Aptekar, 2008). Estou profundamente grata pela assistência de pesquisa que recebi de LaTonya Trotter e Daniel Schneider, responsáveis pela codificação das entrevistas.

** Professora do Departamento de Sociologia, Princeton University e Diretora do Princeton Institute for International and Regional Affaires. knewman@princeton.edu
} 
Laços que prendem

Ties that Bind:

Cultural Interpretations of Delayed Adulthood in

Western Europe and Japan

\begin{abstract}
In the societies where "delayed departure" is common, the structural pressures leading in this direction are similar. Yet the cultural response varies considerably from one society to the next. Comparative analysis across a range of countries suggests that very similar demographic facts come to assume a different degree of significance and distinctive patterns of meaning. Indeed, the main commonality across the delayed departure countries emerges in the policy responses of their governments, which are uniformly worried about the declining birth rate. As for the ordinary citizen, the "failure to launch" varies from a social catastrophe (Japan), to a somewhat milder structural frustration (Spain), to a non-problem (Italy), while for their Nordic counterparts, the ability to launch early is taken in stride, but is accompanied by the nagging sensation that the generations don't need each other as much as perhaps they should.
\end{abstract}

Key Words: Delayed Departure, Japan, Spain, Nordic Countries. 
Num dia morno de primavera, em 2003, me acomodei para um longo almoço num adorável restaurante em Madri, junto com professores $e$ administradores de um centro de pesquisa que estava considerando sua participação numa rede internacional de pesquisadores dedicados ao estudo da desigualdade. Recémchegada à cena de pesquisa espanhola, essa era minha única oportunidade de estabelecer uma conexão intelectual e algumas relações pessoais para facilitar o caminho de nossos alunos de pós graduação no "aprendizado" do instituto. Nossa conversa oscilava facilmente entre nosso trabalho e nossa vida. Eles falavam a respeito do longo efeito do regime de Franco sobre as universidades espanholas e do papel importante que instituições autônomas como a sua tinham tido em manter as ciências sociais vivas durante o regime fascista. Eu falei a respeito de minha pesquisa com os trabalhadores pobres nas cidades norteamericanas.

Depois da terceira taça de vinho, a conversa da mesa passou para a família. A administradora elegante que sentava ao meu lado, uma mulher com cerca de 50 anos, falou com afeto de seu filho de 33 anos que vivia com ela e que trabalhava em tempo integral num emprego em Madri. Como a maior parte das mães de sua geração, ela continuava a ser responsável pela direção de sua unidade doméstica, o que incluía providenciar as refeições de seu filho, cuidar de suas roupas, entre outras necessidades mundanas. Suas colegas espanholas assentiram e pareceram achar o arranjo usual. Espantada com a idéia de um filho em idade tão avançada viver com seus pais, perguntei, tão casualmente quanto pude, o que significava ter seu filho em casa. "Por que ele iria querer me deixar?", ela perguntou em troca.

Um mês depois, eu estava sentada próxima a um belo canal no centro de Aarhus, a segunda maior cidade da Dinamarca. Meu companheiro de jantar era um advogado e juiz em tempo parcial, irmão mais velho de um bom amigo de meus tempos de faculdade. Eu tinha vindo a Aarhus para convidar colegas de ciência política e de economia para a mesma rede, mas tirei a 
Laços que prendem

tarde para visitar esses amigos distantes. Também falamos a respeito de nosso trabalho, mas, naturalmente, migramos para o assunto de nossos filhos. O meu mais jovem estava na escola, faltando ainda seis anos para ir para a faculdade; o filho mais jovem de meu amigo não vivia mais em casa, já que tinha decidido cursar uma formação especial, apenas oferecida em uma escola de outra cidade, muito longe de Aarhus. Aos 16 anos, seu filho tinha juntado suas coisas, se mudado para a cidade, para se matricular na nova escola, se inscrito para uma bolsa do governo que cobrisse suas despesas, e encontrado um teto, com a ajuda da municipalidade, para essa mudança.

Figura 1

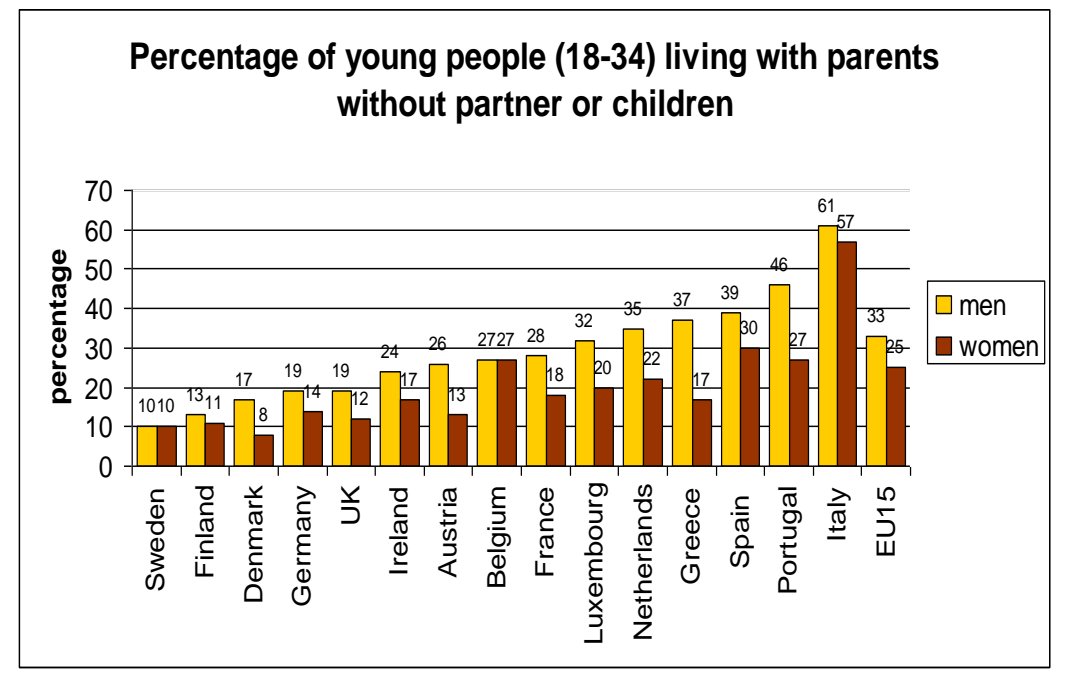

Como fica claro na figura 1, há uma nítida divergência entre os países do norte e do sul da Europa no que diz respeito às escolhas residenciais dos jovens adultos. Hoje, mais de $50 \%$ dos trabalhadores entre 24 e 29 anos da Espanha, Itália e da maioria dos outros países do sul da Europa vivem em suas cidades natais. 
Meus companheiros de lanche na Espanha, assim como meu amigo na Dinamarca, não eram foram do comum.

Esses dois extremos - saída tardia e independência muito cedo - começam a definir um conjunto de tendências na formação de unidades domésticas que chamou a atenção de demógrafos e sociólogos (Cook e Furstenberg, 2002; Billari, 2004; Aassve et alii, 2001; Cherlin et alii, 1997). Cada vez mais, no mundo pós-industrial, temos observado que uma estadia prolongada na casa da família se torna a norma em países com estados de bem estar social frágeis, altos custos de moradia, e com caminhos para o mercado de trabalho cada vez mais difíceis de trilhar para os "jovens". Na outra ponta do universo, especialmente nos países sob regimes social-democratas, vemos estados apoiando experimentos de independência, a continuação da saída de casa que tem sido a marca dos países do norte da Europa desde a Idade Média, quando jovens solteiros deixavam suas casas para trabalhar como empregados nas casas dos ricos.

A forma mais extrema do adiamento em sair de casa talvez seja a do Japão. Entre os homens solteiros com idades entre 30 e 34 anos, mais de $60 \%$ vivem com seus pais; $70 \%$ de mulheres solteiras nesse grupo de idade também vivem com eles. As proporções são ainda mais altas para os solteiros em grupos de idades mais jovens (por exemplo, entre 25 e 29 anos, quando o número sobe para $80 \%$ das mulheres e $64 \%$ dos homens). ${ }^{1}$ Em muitas culturas, incluindo o Japão, o costume é que homens e mulheres jovens vivam com seus pais até se casarem. No caso japonês, no entanto, a idade de casamento está se elevando progressivamente. Em 2006, a idade média de casamento era 28 anos para as mulheres e 30 anos para os homens (Ministério de Relações Internacionais e de Comunicação, 2007), a maior média no mundo desenvolvido.

Porque se desenvolveram padrões tão divergentes e o que eles significam para os cidadãos, jovens e idosos, na Europa e no

${ }^{1}$ Os dados são de Raymo, 2003. 
Laços que prendem

Japão? A primeira questão é facilmente respondida através de uma rápida revisão das mudanças ocorridas no contexto econômico da passagem à idade adulta no sul da Europa e no Japão. A segunda é mais complexa e requer uma abordagem comparativa, qualitativa, com o objetivo de revelar a compreensão subjetiva emergente, e culturalmente marcada, a respeito de autonomia $e$ independência, $e$ das formas apropriadas de apoio - materiais e morais - que definem as relações entre pais e seus filhos adultos.

\section{O "preço da independência"2}

Várias tendências econômicas inter-relacionadas conspiraram para limitar as opções residenciais de jovens adultos no sul da Europa e no Japão. Destacam-se, dentre elas, as condições deletérias do mercado de trabalho. O desemprego sempre foi mais alto no sul da Europa do que no norte, mas, a partir dos anos 1980, o preço da globalização começou a ser sentido de maneira mais forte, levando os governos, na Espanha, no Japão, e em outros lugares, a afrouxar os controles que há muito tempo estimulavam o emprego por tempo indeterminado $e$ de longa duração, de maneira a dar às empresas (pela primeira vez) a flexibilidade de empregar trabalhadores através de contratos temporários ou em tempo parcial (Golsch, 2003; Kosugi, 2004). Trabalhadores mais velhos, com uma posição sólida no mercado de trabalho, foram, no mais das vezes, capazes de evitar as conseqüências; já os trabalhadores mais jovens, e os que buscavam emprego, rapidamente se encontraram num mundo não familiar. Atualmente, por exemplo, mais de um terço dos trabalhadores espanhóis são regulados por contratos de curto

2 Esse é o título do volume da Russel Sage Foundation no qual os dados apresentados nesta seção apareceram num capítulo de K. Newman e S. Aptekar (2008). 
prazo, e mais de 50\% dos trabalhadores homens entre 25 e 29 anos estão sujeitos a esses arranjos de trabalho menos desejáveis.

No Japão, uma tendência semelhante emergiu $e$ foi popularmente reconhecida pelo termo "freeters", denotando indivíduos entre as idades de 15 e 34 anos que "não continuarão seus estudos no ensino superior, nem se tornarão empregados em tempo integral. O mais provável é que eles trabalhem como empregados em tempo parcial, com contratos de emprego de curta duração ou temporários" (Katsumata, 2003:17). A categoria emergiu na cena nacional no final dos anos 1980, quando a "bolha da economia" explodiu e, como na Espanha, o governo respondeu liberalizando os termos dos contratos de trabalho (Kosugi, 2004). Em 1982 havia um número estimado de meio milhão de freeters no Japão. Em 2002, havia dois milhões, que continuavam a crescer (Ministério da Saúde, do Trabalho e do Bem Estar, 2003 apud Honda, 2005:1).

O emprego temporário está fortemente associado com a coresidência dos jovens com seus pais. Como sugere a Figura 2, mesmo sem incluir a Itália (que é um exemplo extremo), o $r=.35$. 
Laços que prendem

\section{Figura 2}

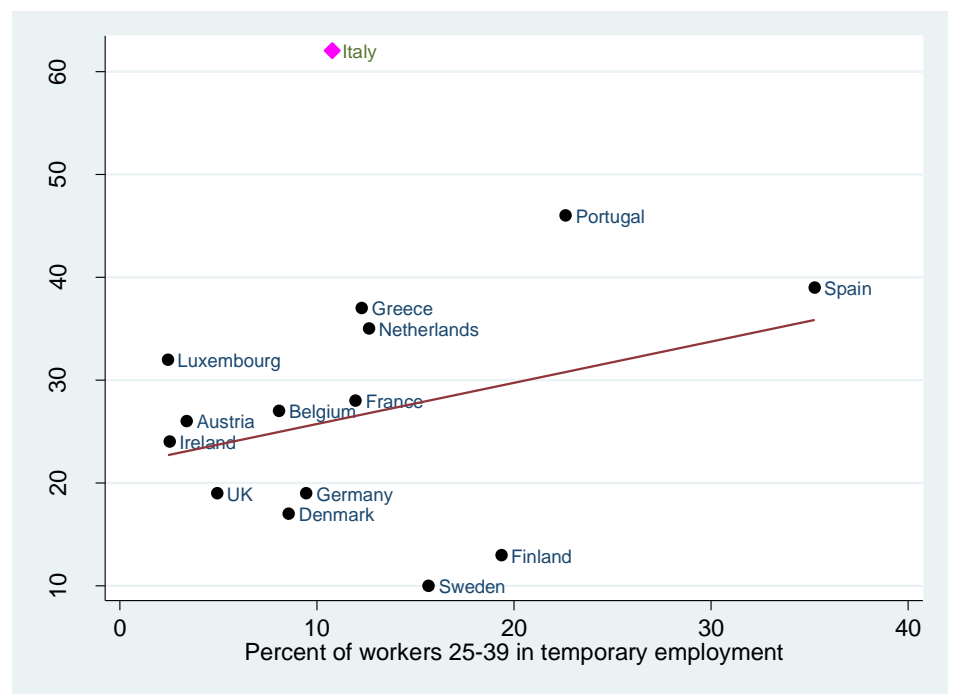

Proporção de pessoas entre 18 e 34 anos vivendo com os pais pela proporção de jovens trabalhadores entre 15 e 39 anos em empregos temporários.

Fonte: Eurostat, Statistical Office of the European Communities, 2003.

Mas isso não se passa em todas as partes; em alguns países (especialmente nos Estados Unidos), os jovens numa posição frágil no mercado de trabalho poderiam escolher dentre uma variedade de opções além da residência com suas famílias de origem. Eles poderiam viver com seus amigos, juntar suas economias com as de um parceiro romântico, e procurar alojamento nos bairros marginais. Ficar com Mamãe e Papai certamente não é a única opção. Mas o é, no entanto, para os jovens que vivem em países com altos níveis de casas ocupadas pelos seus donos. Como mostra a Figura 3, os países do sul da Europa estão nesse caso. Mais de $85 \%$ da população espanhola vive em casas ocupadas por seus donos, e Grécia e Portugal não ficam muito atrás. 


\section{Figura 3}

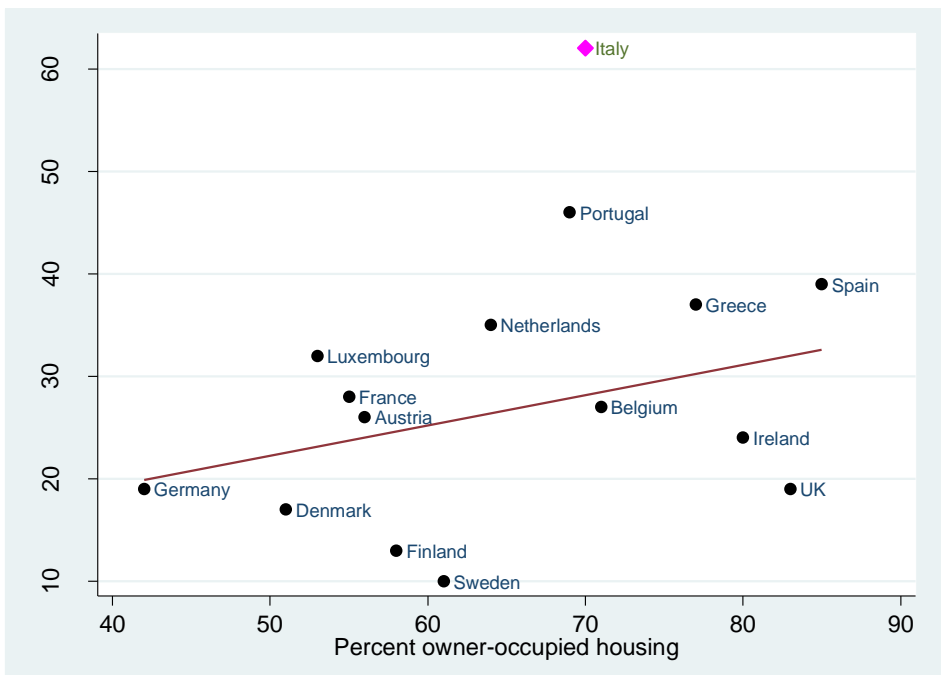

Proporção de pessoas entre 18 e 34 anos vivendo com os pais pela proporção de domicílios próprios.

Sem considerar a Itália, $r=0.37$ Fonte: OECD Economic Review No. 38, 2004/1.

Por outro lado, a propriedade das casas nos países nórdicos, representa apenas entre 60 e $65 \%$ dos casos, e a diferença se explica pela existência de um amplo setor de aluguéis, boa parte dele casas públicas, regulamentadas pelo governo. A disponibilidade de casas para alugar é crítica para pessoas jovens que optam por morar sós sem as economias necessárias para comprar suas próprias casas. Os bancos são céticos a respeito de sua capacidade de ganhar dinheiro, agora agudamente reduzida pelo emprego temporário, e resistem a financiar sua moradia. E, comparados aos Estados Unidos, onde, até à implosão dos empréstimos sub prime de 2008, os bancos rotineiramente concordavam em fazer empréstimos de 80 a $90 \%$ do valor de uma casa, os bancos europeus tipicamente se dispõem a emprestar apenas $50 \%$ deste, aumentando assim as apostas esperadas dos 
Laços que prendem

novos ingressantes no mercado imobiliário para comprar uma casa.

Essas condições estruturais são comuns aos países do sul da Europa na Figura 1 e, vistas em conjunto, não é de surpreender que produzam uma tendência crescente de adultos com menos de 40 anos a ficarem morando com os pais. A combinação das reformas no mercado de trabalho, que colocou em desvantagem os que estão entrando no mundo do trabalho (Golsch, 2003), com altos níveis de casas ocupadas por seus proprietários, é fatal para o desejo de independência residencial dos jovens (Holdsworth, 2000; Holdsworth e Solda, 2002).

Deveríamos esperar que essa situação produzisse muitas frustrações, com os adultos se sentindo infantilizados pela sua dependência residencial, ou tensão nas unidades domésticas que têm mais adultos do que espaço social disponível. Newman e Aptekar (2008) mostraram que a residência prolongada na casa da família, de fato, produz insatisfação. No entanto, quanto mais comum o padrão, menor o estigma. De fato, se morar com os pais se torna a norma para adultos com trinta anos, a sensação de descompasso com outros da mesma idade, diminui, e alguns aspectos positivos da co-residência se tornam mais salientes. De fato, os dados de pesquisas a respeito da satisfação com a vida indicam que os europeus do sul percebem o lado positivo da "saída tardia" de casa (Jurado, 2001), ainda que os governos cheguem a extremos na tentativa de reverter sua conseqüência mais inquietante: a baixa fertilidade.

Mas há variações significativas entre os países a respeito da satisfação com a vida, $e$ as diferenças refletem interpretações divergentes do sentido e do significado social da quaseadolescência prolongada. Em alguns países, o lado positivo é o foco de atenção quando a questão se coloca. Em outros, as frustrações são ampliadas e o problema adquire o estatuto de um "desastre nacional". Além disso, nos estados nórdicos de bem estar social, nos quais os jovens tipicamente saem de casa aos 18 anos e podem contar com o apoio do governo para facilitar sua 
independência (Mulder e Manting, 1994; Muldes e Hooimeijer, 2002), entrevistas em profundidade tornam claro que há "problemas no paraíso" - um emergente conjunto de preocupações com o que a falta de dependência entre gerações significa para a solidariedade social e o bem estar emocional.

\section{Dados comparativos}

Para explorar os entendimentos subjetivos do "fracasso em começar", por um lado, e da "independência acelerada", do outro, avalio agora um conjunto de entrevistas qualitativas em profundidade, feitas pela minha equipe de pesquisa ${ }^{3}$ em quatro países europeus e no Japão no verão de $2006 .{ }^{4}$ Com um total de 250 entrevistas em cinco países, não podemos afirmar de uma maneira definitiva que essas amostras sejam representativas. Ainda assim, um esforço considerável foi feito no sentido de diversificar regionalmente a amostra (por exemplo, sul e centro da Itália; capitais como Madri e Tóquio e regiões rurais no norte da Espanha e da Suécia, áreas ricas e regióes pobres, como Puglia na Itália). Feitas em residências e em cafés, em regiões diferentes de cada país, por falantes nativos das línguas nacionais, as entrevistas incorporam a perspectiva de pais e de filhos adultos nas mesmas famílias, sempre que isso se mostrou possível, e de diferentes

3 Sou imensamente grata a meus entrevistadores, Emanuela Zílio (Itália), Katarina Andersson (Suécia), Marie Kappell (Dinamarca), Maria Gómez Garrido (Espanha) e Noriko Matsumoto (Japão), cuja dedicação à difícil tarefa de criar a amostra e conduzir as entrevistas tornaram possível esta pesquisa.

4 A amostragem pela técnica de "bola de neve" foi feita por assistentes de pesquisa nascidos e criados em cada país, que se apoiaram nos pontos distantes de suas redes pessoais (por exemplo, amigos de seus irmãos que elas não conheciam bem, amigos de conhecidos, etc.). Elas listaram nomes a partir de seus informantes iniciais e selecionaram pelo menos um para continuar e agiram do mesmo modo com cada entrevista. Grande parte da informação recolhida era delicada e alguém mais próximo poderia hesitar em compartilhá-la se pensasse que haveria alguma oportunidade de que suas respostas vazassem para seus filhos ou pais. 
Laços que prendem

famílias quando contatar pais e filhos da mesma família foi percebido como quebra de privacidade. ${ }^{5}$

A tabela 1 apresenta a descrição da amostra de entrevistas realizadas. Nos países de "saída tardia", Espanha, Itália e Japão, enfatizou-se escolher pais com filhos adultos de mais de 22 anos morando na casa ${ }^{6}$ e filhos que vivem com os pais, enquanto que uma menor proporção da amostra exemplificava o estatuto, que escapava à norma, de filhos independentes e seus pais.

5 Na nossa experiência, os pais japoneses não queriam ser entrevistados se seus próprios filhos fossem contatados e vice-versa. Os pais e filhos espanhóis e italianos não apenas reagiram bem à idéia de que ambas as gerações fossem entrevistadas, como frequentemente insistiram para que a entrevista ocorresse na casa da família e pareciam não estar preocupados com privacidade. A norma para pais e filhos nórdicos é viver separados uns dos outros e, assim, mesmo se as entrevistas fossem feitas com gerações diferentes da mesma família, não havia muita preocupação com privacidade entre eles porque eles já eram autônomos.

6 Esse limite de idade foi estabelecido para tentar circunscrever as entrevistas aos filhos já formados, mas isso se mostrou mais difícil do que o esperado, porque em muitos países europeus (incluindo as social-democracias nórdicas), a duração da educação está se prolongando dramaticamente, parcialmente como resposta às menores oportunidades no mercado de trabalho e a um esforço para reduzir a exclusão social. 
Katherine Newman

Tabela 1: Descrição da Amostra

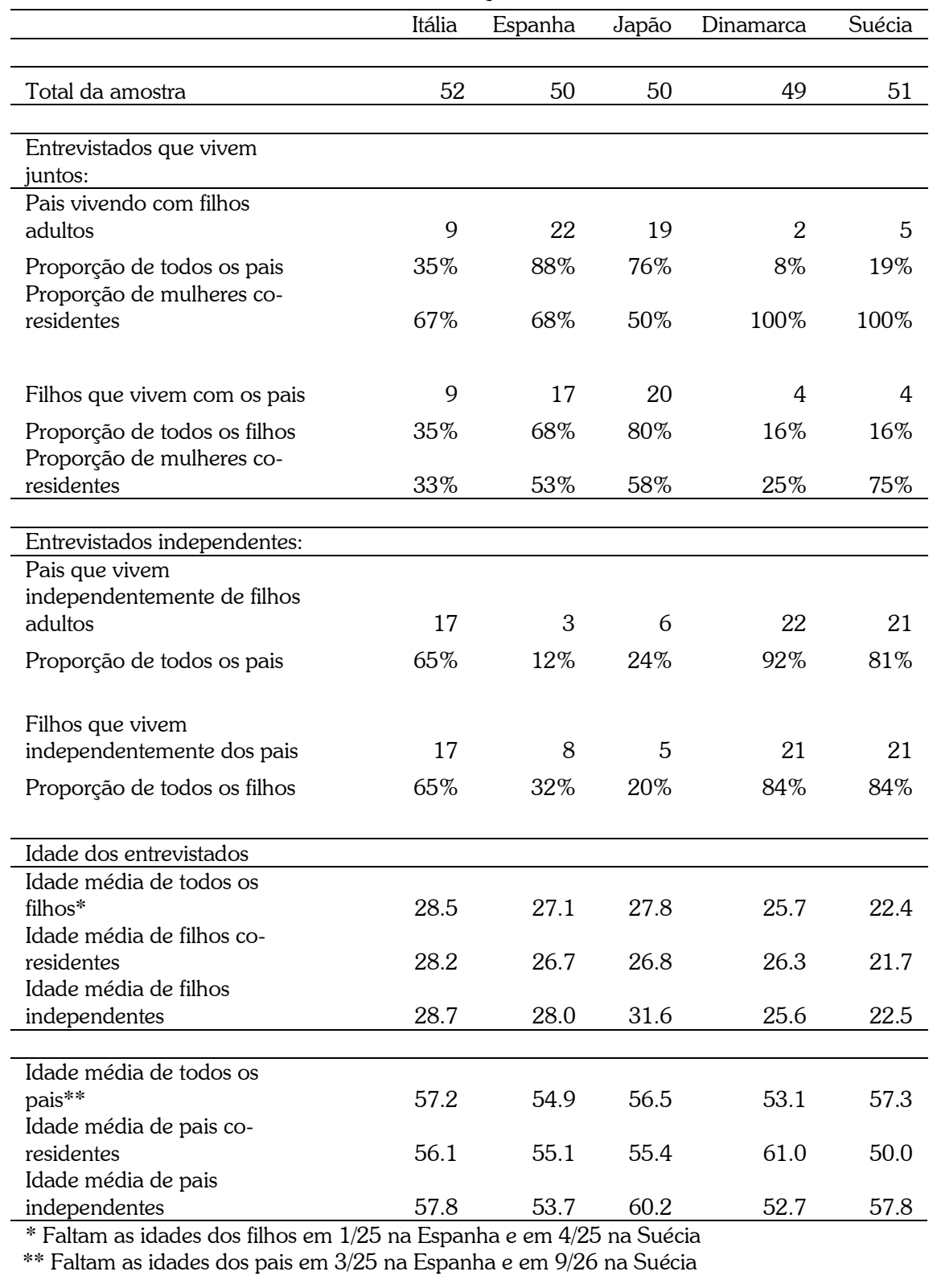


Laços que prendem

O inverso ocorreu nos países nórdicos, Suécia e Dinamarca, nos quais a maior parte da amostra consistiu em filhos não residentes com a família, acima de 22 anos, e seus pais, e uma população "minoritária" de filhos acima dos 22 anos e seus pais. ${ }^{7}$

\section{Sinais de metamorfose}

Nos três países que estudei e nos quais adultos, no final dos vinte anos e no início dos trinta, cada vez mais permanecem na casa da família - Espanha, Itália e Japão - a diferença mais marcante entre as lembranças dos pais sobre sua própria transição para a vida adulta $e$ a percepção que seus filhos têm do mesmo processo, está na passagem de uma transformação abrupta para uma metamorfose lenta $e$ indiferenciada. Para os pais, havia um antes (criança) e um depois (adulto), marcados por claras mudanças de comportamento em suas vidas. Para mães e pais na Espanha, o casamento, o emprego em tempo integral e o nascimento dos filhos eram as linhas divisórias:

Quando vocês eram jovens, o que marcava a entrada na vida adulta?

Ter um emprego... e tornar-se independente. Tão logo você tivesse um emprego, você era parcialmente independente, é claro... Hoje você não é independente porque o dinheiro que você ganha não lhe permite comprar uma casa. Assim, você tem sempre que depender de terceiros, de membros da família, para ajudá-lo. No passado eles também tinham que ajudá-lo, mas não da mesma maneira que as pessoas têm que fazer hoje (Espanha, 59 anos, homem).

7 O filho focalizado como centro de interesse na coleta e análise é aquele filho adulto informante ou o filho ao qual estávamos dirigindo a atenção na entrevista feita com os pais. Isso porque, os pais em nossa amostra frequentemente tinham mais do que um filho, mas nossas questões se dirigiam a um filho específico com mais de 22 anos. 
Katherine Newman

Eu fui marcada pelo casamento. Totalmente. Casei aos 20 anos $e$ isso mudou minha vida.

Isso implicou uma mudança na sua vida.

Sim, totalmente. Foi... a maior mudança na minha vida; sim, penso que sim (Espanha, 45 anos, mulher).

No Japão, do mesmo modo, homens e mulheres mais velhos viam suas vidas como um conjunto bem demarcado de transições entre status,, com linhas nítidas separando suas vidas juvenis de suas vidas adultas. $\mathrm{O}$ casamento era a condição limítrofe crucial:

Ser adulto significa que se pode levar uma vida respeitável. Para cumprir com as responsabilidades sociais, por exemplo. Apenas quando se está criando filhos e levando uma vida respeitável de casado, se pode ser considerado adulto (Japão, 69 anos, homem).

O casamento era o único caminho para nos tornarmos adultos. Já que casar significava sair da casa de seus pais e tornar-se independente, num certo sentido, viver por sua conta. Naquele tempo não havia muitas mulheres que tivessem empregos (Japão, 60 anos, mulher).

$\mathrm{O}$ que ser adulto significa para a geração mais jovem de adultos maduros que vivem com seus pais nesses países? Como eles marcam a transição para a vida adulta quando muitos dos marcadores tradicionais - trabalho em tempo integral, residência independente, casamento - ficaram para trás há anos? Primeiro, eles argumentam que não existem mais marcadores de comportamento da vida adulta. A maturidade é mais um sentimento, uma capacidade de tomar decisões, ou de ter um maior grau de responsabilidade por suas ações. Tais sentimentos podem emergir mesmo no interior das casas de família nas quais algumas das responsabilidades mais prementes que acompanham a independência econômica estão anos adiante: 
Laços que prendem

Então, para você, uma pessoa pode ser um adulto, mesmo se viver com seus pais...

Claro que ele pode ser um adulto... Porque em muitos casos você não pode obter independência antes dos 30. Não considero que eles não sejam adultos. O principal é que você assuma suas responsabilidades, que você assuma suas ações, e que você não dependa de seus pais para tudo (Espanha, 25 anos, homem).

A transição para a vida adulta tem muitos outros estágios e nenhum é canônico ou socialmente reconhecido. A qualidade da mudança, tipo "aos trancos e barrancos", deixa um bom espaço para a ambigüidade e, de fato, ambigüidade é o ethos cultural acentuado. Nossos entrevistados de vinte ou trinta anos têm consciência de que a geração de seus pais podia se apoiar em marcadores de transições de entre status publicamente reconhecidos; por isso mesmo, não podem prescindir inteiramente da idéia de que eles também devem tê-los, ainda que sejam de tipos diferentes. Mas eles não os têm e, como resultado, os espanhóis e japoneses com mais de vinte anos ficam inseguros sobre como se posicionar no continuum adolescente/adulto. Eles sabem que não são mais adolescentes; mas também não se vêem como adultos completos. "Quando eu estava no ginásio", uma japonesa de 28 anos nos disse, "os estudantes do colégio pareciam adultos..."

Mas quando me tornei uma estudante de colégio, não me senti particularmente adulta, Então pensei que, se começasse a trabalhar, poderia sentir que era uma adulta. Mas depois de ter começado a trabalhar, ainda não sinto que seja uma adulta. Claro que acho que ter responsabilidade social significa ser adulto, $e$ nesse sentido agora tenho essa responsabilidade. E minha aparência é a de uma adulta, mas não tenho a sensação de ser adulta.

A mistura de papéis que ela exerce (uma trabalhadora, com idade para ser mãe, mas que é solteira e vive com a família) leva a 
uma alocação ambígua no espectro de papéis numa sociedade que tinha, até a sua geração, critérios muito claros para a assignação de posições sociais.

Dadas as barreiras estruturais que impedem espanhóis e japoneses jovens de viverem por conta própria, poderíamos imaginar que a situação oposta prevaleceria nos países nórdicos. Afinal, sair cedo da casa da família é a norma e nenhum de nossos informantes sugeriu que houvesse um grande obstáculo. Os benefícios educacionais são generosos, residências de transição (dormitórios, casas para alugar, residências públicas) estão disponíveis, e as expectativas de autonomia residencial são generalizadas. Os pais raramente expressam quaisquer reservas a respeito de deixarem seus filhos voar do ninho. Ao contrário, os filhos são estimulados a viver por conta própria $e$ os que permanecem na casa dos pais depois dos 18 anos são vistos como estranhos.

As redes de proteção, que desenvolvemos com base no enfoque político do bem-estar social nórdico, realmente fizeram a diferença [explicou uma mãe sueca de 50 anos]. Suponho que seja um incentivo para toda a nossa política de bem estar social, que você não tenha que ser dependente de outra geração... De acordo com nossos valores, você não deve ficar muito tempo em casa. Espera-se que você saia e se sustente, viva por conta própria.

Ela sabe do que está falando porque ela também saiu de casa muito jovem. Diferentemente dos japoneses e espanhóis, para os quais a experiência de independência dos pais (autonomia residencial muito cedo, em seguida a um casamento também cedo) foi muito diferente da dos seus filhos adultos (independência residencial tardia e casamento tardio), o modelo nórdico está estabelecido há pelo menos três gerações, se não mais. No período anterior à Segunda Guerra Mundial, quando a 
Laços que prendem

Suécia era uma sociedade mais agrária do que é hoje, ficar em casa da família até o casamento - que era tardio - era a norma. Mas a sociedade sueca é muito mais urbana hoje e tem sido assim há décadas. $\mathrm{O}$ apoio que o estado de bem estar social dá a essa experiência de independência juvenil está estabelecido há bastante tempo e assim a experiência das duas gerações entrevistadas para esse projeto é muito semelhante.

Dada essa continuidade, poder-se-ia esperar uma concepção semelhante da transição para a idade adulta em ambas as gerações. Mas não. Nossas entrevistas sugerem que na Suécia e na Dinamarca a geração mais jovem está mais próxima da geração de seus pares que no Japão e na Espanha: tem migrado lentamente em direção a um senso de independência, ao invés de experimentar um nítido antes e depois. A despeito de uma taxa muito alta de autonomia residencial, os nórdicos com mais de 20 anos ainda sentem que estão transitando gradualmente - $e$ passando por muitos estágios indeterminados - em direção à vida adulta. De onde vem a semelhança com sociedades que colocam obstáculos no caminho da independência residencial?

Em primeiro lugar, nossas entrevistas deixaram claro que, embora os jovens suecos e dinamarqueses se mudem, eles não necessariamente vão muito longe. Nossas entrevistas mostraram que muitos jovens adultos vivem perto das casas de suas famílias, mesmo se habitam lugares separados. Frequentemente, eles viviam do outro lado da rua e continuavam a fazer as refeições com suas famílias, particularmente no período dos 18 aos 20 anos. Em segundo lugar, os países nórdicos estão entre os "estados educacionais" mais generosos do mundo e mantém seus jovens na escola por um período de tempo mais longo do que acontece em qualquer outra parte do mundo (Nilsson e Strandh, 1999).

Como mostra a Figura 4, a Holanda, a Dinamarca, a Suécia, a Finlândia e a Noruega têm a mais alta proporção de pessoas no grupo de idade entre 18 e 24 anos na escola, quando comparados ao resto da Europa. 
Katherine Newman

\section{Figura 4}

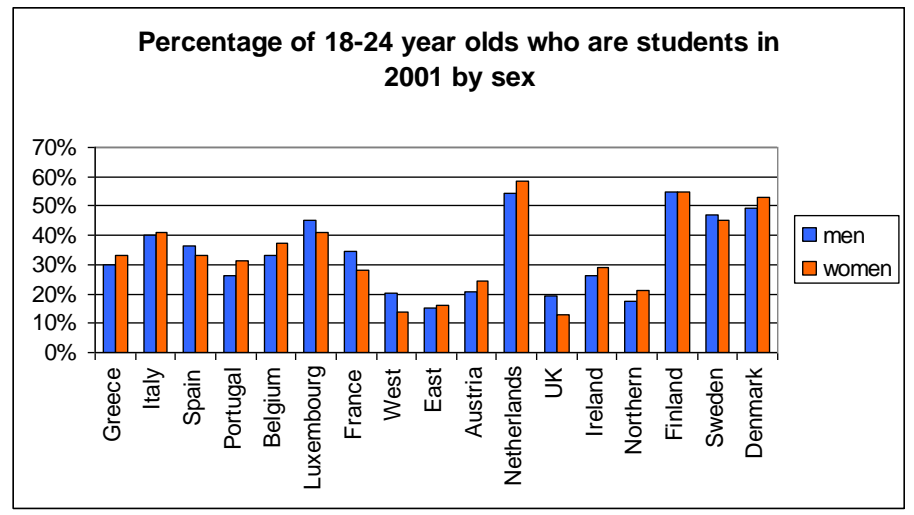

$\mathrm{Na}$ medida em que ser estudante é uma desqualificação para a vida adulta, não é de surpreender que eles se vejam como autônomos em relação às suas famílias, mas não como inteiramente responsáveis por si mesmos.

Seria um equívoco, no entanto, igualar as maneiras pelas quais os europeus do sul e do norte concebem a sua vida adulta, porque numa série de pontos cruciais eles experimentam o lento movimento em direção à independência de modo diferente. No sul, a dependência da família para a sobrevivência econômica dos jovens é muito acentuada, ao passo que, no norte, o laço é muito mais frágil, substituído por ganhos com trabalhos em tempo parcial e por apoio do estado (na forma de ajuda educacional). A Figura 5 mostra que, no Sul, são muito altos - e crescentes- os níveis de dependência econômica dos jovens entre 18 e 24 anos em relação a seus pais; nos países nórdicos, os níveis de responsabilidade dos pais pelo sustento dos filhos são muito baixos, quando não decrescentes como em dois dos casos. 
Laços que prendem

\section{Figura 5}
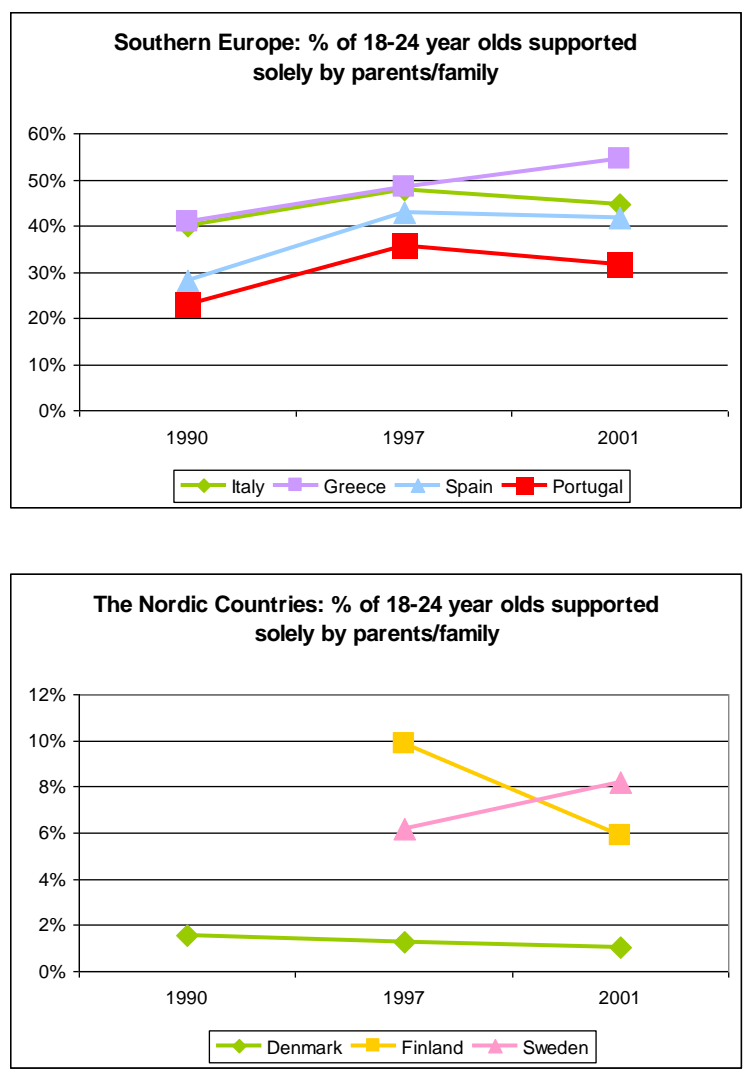

Além disso, como fica claro na Figura 6, a presença de parceiros (especialmente na coabitação) é muito mais alta no norte do que no sul, mais uma vez sugerindo o maior grau de separação da casa da família de origem, mas que ocorre de maneira gradual em termos de sustento econômico individual. 
Figura 6

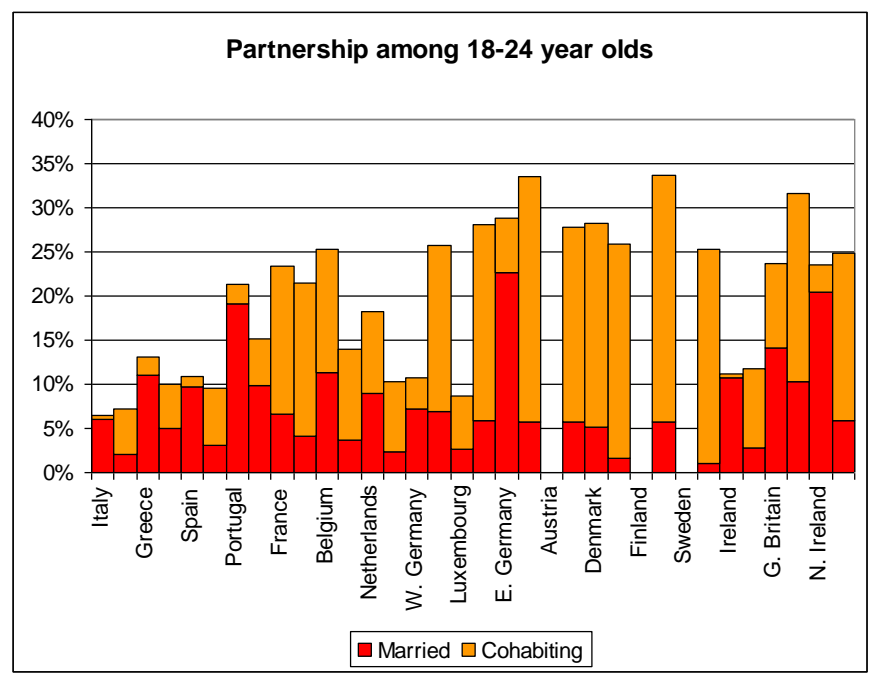

\section{Porque tudo mudou?}

Tendo estabelecido que há diferenças significativas no cotidiano dessas sociedades em termos do processo e do ritmo do movimento em direção à vida adulta, resta compreender porque a mudança teve lugar. Os fatos demográficos apontam para um resultado sobredeterminado conforme já foi explicado. Mas a explicação subjetiva da mudança é outra questão.

No caso da Espanha, os pais que participaram do estudo cresceram sob o regime de Francisco Franco cuja maneira de governar, tradicional e autoritária, provê um vívido pano de fundo para o que se observa no presente. Sob Franco, o controle da natalidade era ilegal, assim como a coabitação. A expectativa, da Igreja Católica e do governo, era de que as pessoas casassem cedo e tivessem filhos logo, e nenhuma alternativa era aceitável. A morte de Franco, em 1975, encerrou esse período, mas deixou para a era moderna duas mudanças culturais fundamentais: (1) um apreço pela flexibilidade e intimidade (por oposição à rigidez e 
Laços que prendem

distância entre as gerações) e (2) uma tendência a explicar experiências pessoais através de lentes estruturais e políticas.

A crescente insegurança econômica dos trabalhadores espanhóis na faixa dos 20 a 30 anos é claramente reconhecida por seus pais como a razão principal para que continuem morando na casa da família. Mas, o quê, por sua vez, produziu tal insegurança? Foi o governo, tal como explicou essa mãe espanhola, com mais de 50 anos.

Quando eu era jovem [ela disse] as pessoas se tornavam independentes mais cedo. ...Tão logo você entrasse numa firma razoavelmente sólida, você sabia que tinha...[segurança], tal qual um funcionário público. Você podia procurar uma casa numa determinada área, porque você sabia que "eu trabalho aqui". Mas hoje, você nunca sabe. Talvez você esteja trabalhando um ano e talvez no ano seguinte você esteja num outro trabalho. E com esses contratos fajutos, as pessoas nunca podem se tornar independentes. Você encontra pessoas de trinta e quarenta anos em casa. Mas não é porque eles não queiram ir... É só porque eles não podem sair.

Os "contratos fajutos" que ela despreza não vieram do ar; foram resultado de leis aprovadas pelo governo espanhol com a intenção de oferecer maior flexibilidade para as empresas, como uma maneira de responder às pressões da globalização. Um prolongado sistema de educação superior, que não é acompanhado por oportunidades profissionais de emprego, deixa os trabalhadores espanhóis super-qualificados para os empregos que estão disponíveis, e frustrados pelo hiato entre suas expectativas e as realidades que encontram. Nem os pais, nem os filhos adultos, olham para dentro de si para descobrir a causa de seu desconforto; eles olham por cima do ombro, para o governo, para o mundo das corporações, para as elites e outros atores poderosos que definiram suas opções de cima para baixo. De fato, em 2007, houve greves em Madri para protestar contra o alto 
preço dos aluguéis e exigir a intervenção do governo a favor dos jovens que estão no lado mais fraco da corda que representa esse mercado imobiliário absurdamente caro.

A explicação japonesa para a dependência prolongada não poderia ser mais distinta. A despeito do fato de que o Japão viveu a experiência de uma "bolha" econômica, que dificilmente contratava, ampliando o desemprego e criando condições para a emergência do trabalhador temporário - o freeter, referido anteriormente - as narrativas que explicam as mudanças nos padrões de passagem para a vida adulta não fazem virtualmente qualquer referência a essas condições estruturais.

Ao invés disso, do mesmo modo que os norte-americanos entrevistados por Newman (1993) 15 anos atrás, que tentavam explicar a mobilidade descendente entre gerações e o 'fracasso' dos jovens em se tornarem mais autônomos de seus pais, os japoneses também escolhem uma narrativa moral de culpa. Mães e pais argumentam que a geração mais jovem está estragada pela riqueza, paralisada por um excesso de escolhas, e que chegou aos 20 anos mal-formada. Como foi que essa triste situação foi criada?

Nós a criamos, [dizem os pais da geração do aumento da natalidade]. Como crescemos numa época muito dura, nossa geração estragou nossos filhos, na disciplina $e$ na educação em casa. O que vemos na sociedade hoje é o resultado disso. Nós, da geração do aumento da natalidade, crescemos num tempo difícil. Assim, queríamos tornar fácil a vida de nossos filhos - acho que isso vale para qualquer família. Acho que a maior parte dos problemas dos jovens hoje deriva de nossa geração. Somos responsáveis por isso, por exemplo, através da disciplina em casa (Japão, 57 anos, homem).

Se os norte-americanos tiveram no pós- guerra seu período mais equilibrado de prosperidade econômica na história moderna do país, a economia japonesa levou muito mais tempo para se recuperar das destruições decorrentes da Segunda Guerra 
Laços que prendem

Mundial. Assim, a geração do "baby boom" no Japão cresceu em meio a dificuldades, mas viveu a sua vida adulta num surpreendente período de crescimento econômico. Como esse pai explica, eles quiseram proteger seus filhos daquilo que tinham sofrido e, de seu ponto de vista, levaram as coisas muito longe: eles estragaram seus filhos e falharam em lhes dar o tipo de disciplina necessária para chegar à vida adulta na época contemporânea.

Da perspectiva dos pais dessa geração, os jovens japoneses não querem mais fazer concessões às demandas da sociedade $e$ ocupar o seu lugar na estrutura social. As mulheres não querem mais servir aos pais de seus maridos, como era norma absoluta no passado. Os homens jovens não querem se atrelar às corporações. $\mathrm{E}$, tanto homens como mulheres, são mais auto-centrados $e$ menos devotados aos outros. Como afirmou uma japonesa de meia idade:

Se eles [os jovens adultos] criarem filhos, não terão tempo livre suficiente para si mesmos...

Eles não seriam tão livres. Sinto que há muitas pessoas que pensam egoisticamente assim. Os jovens não têm a percepção de que ter filhos é uma obrigação.

Mas os mais velhos não são os únicos a partilhar essa percepção negativa acerca da geração mais jovem. Os jovens adultos nas nossas entrevistas também concordam, como fica claro no que diz esse homem de 23 anos:

No passado, acho que as pessoas queriam ter filhos assim que casassem. Se os gastos necessários para isso aumentavam, eles trabalhavam para cobrir esses gastos... Hoje, as pessoas pensam primeiro nos gastos necessários para si mesmas. Só depois pensam nos quanto podem gastar com seus filhos. 
O período de crescente sucesso econômico do Japão foi acompanhado pela emergência do bem conhecido adicto ao trabalho, o "homem assalariado". Enquanto as mães ficavam em casa para criar os filhos, os pais, nos mercados de trabalho primários das suas corporações, davam suas vidas para a empresa. O espectro dos pais que "trabalhavam até a morte", que passavam seis dias da semana longe de casa, e suas noites bebendo na companhia de colegas de trabalho, levou a uma percepção retrospectiva de que o "pai ausente" é o responsável pela decadência moral dos jovens que têm, hoje, por volta de trinta anos.

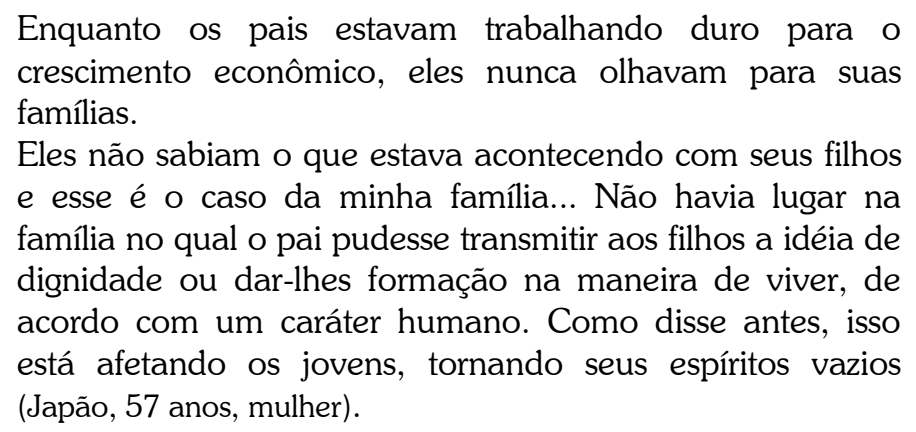

O pai ausente e a mãe solitária não são tão centrais nos diagnósticos populares sobre os problemas da estrutura familiar japonesa (pelo menos não tão centrais como os "solteiros parasitas" [Genda, 2000; Lunsing, 2003], ou os freeters), mas eles emergem em nossas entrevistas sobre o porquê de os jovens adultos de hoje estarem abandonando os caminhos estabelecidos em direção a uma vida adulta responsável. Os pais percebem que uma crítica retrospectiva da família tradicional do pós-guerra está ganhando força, e que ela pode iluminar de maneira negativa a vida de casados dos mais velhos.

Me pergunto se nossa vida de casados parecia infeliz para [minha filha, refletia uma mãe japonesa de 60 anos]. Esta 
Laços que prendem

pode ser a razão pela qual ela não consegue se decidir a casar...

Trabalhei duro como mãe e estava fazendo o papel de uma nora e de uma esposa. Eu pensava que era muito feliz. Mas talvez [minha filha] estivesse realmente olhando para o que se passava no interior da família [risos]. Ela estava lendo a realidade. Assim, agora penso que, quem sabe, não fossemos tão felizes. Esta é a razão pela qual ela não tem esperanças, ou sonhos, de casamento... Há muitas situações nas quais os pais se enganam mutuamente sobre sua vida de casados. Acho que os filhos percebem isso $e$ talvez essa seja a razão pela qual haja tantos jovens que não se casam (Japão, 60 anos, mulher).

Num nítido contraste com os entrevistados italianos ou espanhóis, que enfatizam as dificuldades que os jovens encontram para achar bons empregos ou casas que possam pagar, os informantes japoneses atribuem a mudança entre gerações a dilemas e fracassos morais, catalisados pelo clima interno da família ou pelas práticas questionáveis de socialização postas em pratica pela geração mais velha.

Âs vezes essas interpretações moralistas beiram a histeria social, como quando os entrevistados descrevem desintegração da própria estrutura social do país sob o peso das mudanças. ${ }^{8}$

Eles falam num tom catastrófico sobre a desintegração da solidariedade e sobre traumas nunca antes mencionados como tendo se tornado corriqueiros. A emergência dos hikikomori, homens jovens que se trancaram em seus quartos e se recusavam a sair - durante anos - capturou o lado escuro da imaginação japonesa. Exemplos de crimes inimagináveis cometidos no âmbito familiar são alvo de uma avalanche de notícias na imprensa. Por que tais formas de desvios têm se tornado tão comuns? Essa mãe de 66 anos entende perfeitamente o que aconteceu:

8 Para uma análise mais detalhada das preocupações dos japoneses com o colapso social, ver David Heheny (2006). 
Katherine Newman

Digamos que o pai é o homem de uma corporação e não se preocupa com sua família. Sua família pode viver com seu salário, mas crianças não crescem só com dinheiro. Desse modo, as crianças não podem crescer adequadamente. Daí porque coisas como os hikikomori estão acontecendo, ou mesmo quando os jovens arranjam um emprego, eles param de ir trabalhar. Quando a criança é pequena, isso se manifesta na sua recusa em ir à escola. Em outras palavras, as crianças são vítimas. Além disso, o que é mais visível hoje é a violência doméstica, o assassinato de membros da família. Acho que a raiz dos problemas está aí [no enfraquecimento das relações familiares].

Um pai com mais de 50 anos concorda, e tem sua própria visão apocalíptica:

[Os jovens] tratam a vida humana de maneira leviana... Há notícias de que eles enterraram alguém enquanto ele ou ela ainda estavam vivos, ou mataram alguém - há muitos casos como esses. Isso acontece porque eles vêem outros seres humanos apenas como coisas (Japão, 59 anos, homem).

Os pais da geração do aumento da natalidade não estão sozinhos em sua percepção terrível do colapso social. Seus filhos vêem a situação de maneira semelhante:

Recentemente ocorreu um caso no Japão: uma moça estava dando veneno para sua mãe beber e mantinha um diário com observações sobre ela. Os jovens estão confusos a respeito do mundo real e do mundo de fantasia que eles criam. $\mathrm{O}$ número de crianças, ou jovens, que não sabem a diferença entre o virtual e o real, parece estar aumentando (Japão, 28 anos, mulher). 
Laços que prendem

Em nenhuma de nossas outras entrevistas encontramos evidência de uma tal preocupação com os fundamentos do tecido social, nem mesmo no sul da Itália onde a violência cotidiana é mais do que uma possibilidade ocasional. No Japão, vemos uma preocupação real em relação ao futuro do país e um relato moralista a respeito de como esses problemas se desenvolveram originalmente: eles foram criados pelos próprios pais.

\section{O lado positivo}

Embora a permanência no ninho de nascimento signifique que independência de fato é um objetivo distante, o laço entre pais e filhos está, não obstante, se modificando em direção a um estado diferente do típico relacionamento "de cima para baixo", característico da adolescência. Entre a autonomia adulta e a dependência infantil localiza-se o estado intermediário da "vida adulta na casa dos pais"; uma relação mais igualitária que permite que o filho, ou filha, adultos, entrem e saiam, ou desenvolvam relações íntimas com outros, mantendo, ao mesmo tempo, uma relação íntima com seus pais. Essa evolução pode ser suave ou acidentada, dependendo de quanta autonomia o filho ou filha requeira e do nível de conforto de seus pais com respeito a esta "criatura nova" em seu meio. Mas pode se tornar também uma fonte de prazer genuíno e para ambas as partes, mesmo quando formas de coerção econômica (um mercado de trabalho adverso, contratos de curto prazo, custos exorbitantes de moradia) tenham tornado o arranjo necessário.

O prazer deriva frequentemente de uma experiência contrastante, ao menos se comparada com o que a geração mais velha bem se lembra quando recorda o que foi a sua própria infância. Quando eles olham para trás, lembram-se de suas relações com os pais, como marcadas pela distância emocional, numa mistura de respeito e medo. Uma mãe espanhola, com cerca de 60 anos, lembrava-se de que seu pai raramente estava em casa e, quando estava, ela ficava fora de seu caminho, de 
maneira a evitar desaprovação. "Meu pai nunca encostou a mão em nós [reconheceu ela], mas com um simples olhar dele, ficávamos mortos". Ela não quis também esse tipo de relação com seus próprios filhos. Ao invés disso, ela queria estar certa de que eles confiassem nela e no pai e que se sentissem emocionalmente próximos. "Esse [medo] nunca existiu na geração de meus filhos", ela observou com certo orgulho. "Eu não queria que existisse $e$ meu marido também não queria".

Essa vontade de uma relação mais próxima ajuda a manter um contato mais flexível conforme o papel do filho adulto na casa muda com a idade. Ao invés de os pais sentirem que estão sufocando seu filho adulto, eles percebem os aspectos positivos em sua afeição e proximidade continuadas.

Vejo meus filhos se sentirem em casa aqui, felizes [explicou uma mãe espanhola de 53 anos].

Não senti que eles estivessem inibidos ou intimidados, ou... por exemplo, com raiva, por ainda estarem em casa. Eles sabem que... aqui a porta está sempre aberta. A cadeira e a mesa para sentar e falar... Entendo que isso possa ser um problema em certas casas... porque... viver juntos pode ser difícil para eles, [mas]... Meus filhos nunca me perturbaram, nem nunca o farão, acredito. Ao contrário.

Sua filha, com quase 30 anos, via a relação em termos análogos, igualitários:

Temos uma relação mais pessoal com nossos pais. Posso lhes dizer muito mais coisas, acho que eles nos conhecem melhor do que os pais deles os conheciam... Podemos ser influenciados pelas opiniões de nossos pais, mas não é uma imposição, como era no passado. Como quando meus pais iam comprar uma casa $e$ isso era algo que eles tinham que discutir com meus avós. E não acho que isso aconteça mais. 
Laços que prendem

Os pais japoneses também relataram o mesmo tipo de abrandamento em sua relação com os filhos e percebiam o mesmo contraste com sua própria experiência de uma infância regrada por pais mais austeros e distantes. Alguns concordaram com seus pares espanhóis em que a abordagem moderna de empatia e apoio dos pais em relação aos filhos era uma benção. Outros não estavam tão seguros. A igualdade pode levar à falta de respeito, de acordo com muitos pais. "Os pais não encaram seus filhos com confiança", disse uma mãe de 51 anos, de Tóquio, que parecia lamentar o fim do modelo patriarcal.

O pai costumava ser chamado de o esteio da familia - havia uma pessoa na família a quem os filhos não podiam desobedecer. Ainda há famílias assim, mas, geralmente, pais e filhos se relacionam como se fossem amigos. A conseqüência desse tipo de relacionamento é que os filhos começam a pensar que qualquer coisa que eles digam será aceita. Eles se tornam intolerantes.

\section{Tristeza nórdica}

Para os norte-americanos, os países nórdicos parecem, à primeira vista, algo próximo do nirvana. Com efeito, as decisões que colocam os maiores desafios para os adultos e os jovens em outras sociedades - ir para a universidade, viver independentemente, encontrar centros de cuidados de crianças ou velhos - são limitadas pelas finanças. A generosidade do estado do bem estar na Suécia e na Dinamarca elimina essas preocupações. De fato, a maior responsabilidade de pais e filhos diz respeito a verificar se os serviços oferecidos pelo estado estão sendo adequadamente administrados (e não se pode pagar por eles). A educação universitária é grátis, os serviços de saúde são universais e baratos, os cuidados de crianças e de velhos são abundantes e na sua maioria gratuitos. As social-democracia são particularmente generosas com os jovens, oferecendo amplos benefícios educacionais e subsidiando os mais longos períodos de educação universitária no mundo ocidental. 
Esse apoio excepcional é oferecido através de uma relação direta entre o cidadão 9 e o Estado. Enquanto os Estados europeus do sul direcionam seja qual for o benefício social aos quais os seus cidadãos tenham direito através do chefe de família, os estados do norte desenvolveram uma tradição diferente. Cada residente tem direito a benefícios específicos, não importando a configuração de sua unidade doméstica, ou estatuto marital, e esses recursos são destinados a eles como indivíduos e não como filhas, filhos ou esposas.

É difícil para os norte-americanos, ou europeus do sul, imaginar que qualquer coisa possa perturbar os escandinavos a respeito do seu sistema social (fora, talvez, as altas taxas que eles pagam para fazê-lo funcionar). Ainda assim, as entrevistas com pais suecos e dinamarqueses e seus filhos adultos, a imensa maioria dos quais vive independentemente uns dos outros desde que a geração mais jovem atingiu os 18 anos, sugere que a ausência de dependência pode enfraquecer os laços entre as gerações.

As redes de proteção, que desenvolvemos com base no enfoque político do bem-estar social nórdico, realmente fizeram a diferença [explicou uma mãe sueca de 50 anos].

Você não deve ser dependente de outra geração... De acordo com nossos valores, você não deve ficar muito tempo em casa. Espera-se que você saia e se sustente, viva por conta própria.

Isso poderia ser visto como uma virtude, porque os filhos não são obrigados a voltar para os braços de seus pais para sobreviver economicamente. Ao invés disso, eles podem escolher o nível de interação que têm com suas famílias. No entanto, os jovens de nossa amostra preocupam-se com o fato de que sua

\footnotetext{
9 A maior parte desse apoio está disponível para todos os residentes, independente de cidadania.
} 
Laços que prendem

cultura se tornou muito distante, como se a falta de dependência financeira tivesse criado uma distância emocional que consideram pouco saudável.

Comparando-os com outros [disse uma jovem de 22 anos], os dinamarqueses são um punhado de criaturas sem raízes.

Isso se deve ao fato de que saímos de casa muito cedo, mas também ao fato de que somos individualistas. Não sei se isso seria diferente se não saíssemos tão cedo... Talvez se você ficasse com seus pais um pouco mais, você não sentisse que não tinha recebido amor suficiente.

Quando perguntado por que a Dinamarca é tão diferente da Itália em relação ao padrão de saída de casa, um jovem (25 anos) explicou que nos países do sul "as pessoas se importam mais em estar com suas famílias. E não se incomodam de viver perto umas das outras". Ele via sua própria cultura como intolerante com respeito a esse tipo de intimidade, quase fugindo dela. "Na Dinamarca [observou ele] as pessoas provavelmente não aceitariam dividir um quarto com um irmão".

Nos países nórdicos, os jovens não eram os únicos a sentir que suas sociedades estavam sofrendo com a distância entre as gerações. Uma sueca de meia idade tentou explicar como a extrema preocupação de cada geração com sua vida íntima podia afetar os jovens:

Muitos jovens são deixados à sua própria sorte, enquanto seus pais estão ligados nas suas carreiras. Quero dizer, o que pode acontecer com essas crianças, elas podem acabar tendo um problema mental, ou talvez vir a se tornar alcoólatras.

Nas entrevistas para esse projeto, tentamos entender a natureza cambiante das relações entre pais e filhos nos cinco países, perguntando aos pais que tipo de responsabilidade eles tinham em relação aos seus filhos de 15, 20, 25 e 30 anos. Os pais consideram que cumpriram com suas obrigações quando os filhos 
têm uma idade muito baixa porque o estado passa a assumi-las. "De acordo com a lei", me disse uma mãe sueca de meia idade, "temos responsabilidade de ser provedores de nossos filhos até que eles tenham 20 anos, pouco mais ou menos... até que tenham completado o colégio". Mas, continuou ela, quanto mais cedo um filho possa ser desmamado dos recursos familiares e redirecionado para as autoridades municipais, melhor:

Acho que tão logo você tenha concluído os estudos e ainda não tenha um trabalho por causa da estrutura da nossa sociedade, você deve ser capaz de substituir o que lhe damos pela ajuda das agências de trabalho... ou seja lá quem for que toma conta disso. E se isso não for possível, ou se você precisar mais, você pode procurar as autoridades do sistema de bem-estar social [socialem].

Diferentemente das sociedades do sul da Europa e do Japão, os países nórdicos experimentaram uma mudança muito pequena nos padrões de independência entre as gerações. A social-democracia trouxe a esses países um estado de bem estar social generoso que está instalado há três gerações e, assim, as normas de uma independência atingida ainda cedo $e$ a conseqüente falta de interdependência financeira são fatos da vida. Se isso trouxe grandes benefícios para os residentes nórdicos, também os fez pensar, por vezes, se não teriam criado uma ordem social mais anômica do que seria almejada. E isso não é novo; esta preocupação desconfortável tem sobrevivido por muitos anos.

\section{Ameaças culturais}

Até aqui tratei principalmente das dimensões inter-pessoais da mudança demográfica que fez com que os adultos do sul da Europa e do Japão passassem a maior parte do seu tempo, aos 20 e 30 anos, em co-residência com seus pais. As interpretações que eles oferecem do significado dessa mudança são tingidas pela 
Laços que prendem

frustração política (na Espanha), a afeição pessoal (na Itália) e a condenação das deficiências culturais das gerações mais jovens (no Japão). Ainda assim, nos três países há um outro refrão presente que focaliza menos as conseqüencias pessoais e mais as conseqüências nacionais das mudanças que estão ocorrendo na formação das unidades domésticas.

A independência tardia, a formação lenta das unidades domésticas, e o declínio na fecundidade coincidiram com um aumento na migração proveniente de suas antigas colônias. Do mesmo modo que nos Estados Unidos, os níveis de fecundidade são mais altos entre os recém chegados do que entre os nativos. ${ }^{10}$ Sob esse prisma, esta poderia parecer uma boa solução para a praga da "escassez de nascimentos" que assola a Europa ocidental, e algo que o Japão (com seus níveis extremamente baixos de imigração) bem que poderia vir a estimular. Conquanto o efetivo aumento na imigração se destine ao preenchimento de oportunidades nos níveis mais baixos no mercado de trabalho, ele cria pressões sobre as políticas de bem-estar social dos países nórdicos e contribui para uma crescente xenofobia no sul da Europa, pouco familiarizados com a tradição de imigração e com a diversidade étnica por ela produzida.

Os pais espanhóis, que reconhecem que seus próprios filhos adultos atrasaram o nascimento da geração seguinte, estão conscientes de que os imigrantes estão na dianteira na tarefa de constituírem família.

As famílias espanholas cada vez têm menos filhos [explicou um homem de cerca de 50 anos]

Vejo que os estrangeiros têm mais filhos. São eles que estão elevando a taxa de nascimentos porque, se não fosse assim, o que faríamos? [risos]. Mas as famílias espanholas estão tendo cada vez menos filhos.

${ }^{10}$ Westoff e Frejka (2007) mostram que famílias muçulmanas na Europa ocidental têm mais filhos do que as não muçulmanas, mas o tamanho da família cai em cada geração, assim como está caindo nos seus países de origem. 
Essa não é uma observação neutra. Os espanhóis mais velhos acreditam que as altas taxas de natalidade dos estrangeiros, acopladas à baixa fecundidade dos nativos, vão alterar o caráter do país: ele não será mais a Espanha. Outra senhora de cerca de 50 anos concordava com esta observação e pensava que as autoridades deveriam fazer algo para reverter essa tendência. "Acho que o governo... deveria fazer algo", disse ela.

Se continuarmos assim, estamos tomando o caminho errado. O caminho errado. Teremos de trazer ainda mais estrangeiros do que os que já temos. E não acho que isso seja positivo.

Os estados nórdicos não tiveram quedas tão vertiginosas de fecundidade, mas também ali se expressa preocupação com os imigrantes porque percebem os recém-chegados como mais conservadores e, portanto, menos tolerantes com respeito às suas liberdades culturais. Ainda mais preocupante para muitos nas social-democracias é a possibilidade de que os novos imigrantes se tornem tutelados permanentes do estado de bem estar social em vez de trabalhadores que participam de sua economia. ${ }^{11}$ No entanto, esse medo não diz respeito exclusivamente aos imigrantes. Entrevistados dinamarqueses e suecos frequentemente expressaram a opinião de que também para os nativos tornara-se rotina cair na dependência do Estado. Como explicou um jovem (29 anos): "A Dinamarca é o tipo de país no qual um monte de pessoas tem uma atitude muito conveniente em relação a um monte de coisas como [a assistência pelo estado]".

É muito fácil não se preocupar com nada. É muito fácil não ter emprego e ainda assim receber, algumas pessoas não têm de lutar por essas coisas. Acho que o sistema todo deveria ser

${ }^{11}$ Uma das razões pelas quais isso provoca preocupação é que em alguns países nórdicos os não cidadãos não têm direito a trabalhar e, portanto, são quase por definição incapazes de se juntar à força de trabalho e misturar-se à cena do mercado de trabalho. 
Laços que prendem

mudado. Mas isto também tem sido objeto de discussão, algumas pessoas não querem trabalhar, preferem viver da previdência.

Ele acrescentou rapidamente que os benefícios do estado eram tão generosos que há muito tempo se igualavam aos ganhos de um salário mínimo, o que reduzia o incentivo a trabalhar.

Essas preocupações parecem estar muito longe do objetivo central deste artigo, que é a entrada tardia na vida adulta. Mas, para nossos informantes, a conexão era clara: a dependência continuada da família leva a um declínio nas taxas de nascimento e a uma concomitante dependência da nação frente aos imigrantes que acorrem à Europa. Mas sua presença catalisa sentimentos nativistas porque países que foram relativamente homogêneos estão se tornando mais diversificados. Eles ainda são espanhóis ou italianos? Essa é uma pergunta importante na nova Europa e a resposta é difícil, qualificada, e propensa a expressões explosivas, como vimos em países como a Dinamarca ${ }^{12}$, legendários por sua tolerância e conduta socialmente igualitária.

\section{Conclusão}

As economias desenvolvidas do Ocidente e do Leste estão todas assistindo a um prolongamento do caminho que leva à vida adulta. Nos países nórdicos, a independência residencial é facilmente alcançada, mas a duração da educação está aumentando e a "sensação" de que não se alcançou um patamar de autonomia é palpável tanto entre os escandinavos com mais de vinte anos quanto entre seus pares no Japão, na Espanha ou na Itália. Jovens suecos e dinamarqueses tornam-se aptos a viver por conta própria desde bem cedo e a experimentar a vida com

\footnotetext{
${ }^{12}$ A publicação de doze cartuns editoriais dinamarqueses no Jyllands-Posten, fazendo humor com o profeta Maomé, testando os limites da censura, provocou uma reação raivosa de todo o mundo islâmico em 2005. Os cartuns eram acompanhados por um texto que levantava a questão de se os muçulmanos poderiam se integrar à uma sociedade secular que acredita na liberdade da palavra.
} 
companheiros numa sociedade tolerante. No entanto, essa liberdade é possível pela dependência do Estado, por vias que os pais e filhos dos países nórdicos já não estão tão certos de que sejam virtuosas. Eles estão preocupados com o fato de que a dependência do apoio do governo tenha tornado obsoletos os laços que deveriam unir as gerações.

Nas sociedades nas quais a "saída tardia" é comum, as pressões estruturais que os conduzem nessa direção são semelhantes: perspectivas frágeis no mercado de trabalho para jovens adultos, dependência de moradias ocupadas pelos proprietários, que requerem mais capital do que o que está acessível a trabalhadores com contratos temporários, e uma geração mais velha e rica que pode se permitir dar guarida à geração seguinte. No entanto, a resposta cultural varia consideravelmente de uma sociedade para outra. Deixando de lado, temporariamente, as nuances que dividem os entrevistados por classe ou região no interior de seus países, vemos uma interpretação dominante emergir em cada país. Dizendo-o de maneira geral, nossos entrevistados italianos estavam fundamentalmente contentes com as unidades domésticas multigeracionais que surgiram entre eles $e$, conquanto estivessem preocupados com a mobilidade descendente, eles raramente se importavam com as conseqüências de um começo tardio da geração seguinte per se. Por vezes se queixavam, mas não atribuíam culpas.

Seus pares espanhóis eram bem mais políticos ao interpretarem essa lentidão. Eles culpavam o governo, $e$ talvez o mundo das corporações, por tornarem impossível a independência dos jovens aos vinte anos. Eles chegam a apontar a data (em 1985) na qual os empregos de longa duração se tornaram obsoletos diante da criação de novas regras contratuais que asseguraram que os novos ingressantes no mercado encontrariam basicamente empregos de tempo parcial ou de curta duração. Os pais e filhos espanhóis admitem que existem benefícios em sua continuada co-residência, uma espécie de 
Laços que prendem

intimidade emocional que eles valorizam por contraste com as austeras relações entre pais e filhos no passado. Mas a nuvem negra que cerca essa linha prateada lhes é evidente e eles têm plena certeza sobre a quem atribuir a responsabilidade por essa guinada na situação.

O Japão experimentou um desastre econômico agudo na forma da "explosão de uma bolha", nos anos 1990, à qual se seguiu uma recessão que foi excepcionalmente persistente. De todos os países nesse estudo, talvez fosse o mais preparado para entender a experiência pessoal como conseqüência de uma mudança estrutural. Não há menção à crise econômica que eles suportaram. Ao invés disso, emerge uma subjetividade de base fortemente moral, na qual os agentes da vida adulta tardia são ou os pais, que foram muito lenientes com seus filhos, ao abandonarem suas famílias em prol do trabalho, ou a geração atual de jovens que - em virtude de suas próprias inclinações recusa-se a aceitar de bom grado as responsabilidades que supostamente chegam com a idade.

A análise comparativa entre esses vários países sugere que fatores demográficos muito semelhantes assumem um grau diferente de significação e distintos padrões de sentido. De fato, o que há de mais comum entre os países a respeito da saída tardia de casa, são as respostas políticas de seus governos, uniformemente preocupados com o declínio da taxa de nascimentos. Quanto aos cidadãos comuns, o "fracasso em começar" varia de uma catástrofe social (Japão), passando por uma frustração estrutural mais leve (Espanha) até a não problematização, quando, para seus pares nórdicos, a capacidade de começar cedo é enfrentada sem hesitação, mas acompanhada pela aborrecida sensação de que as gerações não precisam tanto uma da outra como de fato deveriam precisar. Muita independência se parece muito com anomia.

Uma sociologia da cultura tem muito a oferecer na compreensão do significado dessas tendências demográficas que estão definindo novos padrões de formação de unidades 
Katherine Newman

domésticas e redefinindo as instituições básicas da família, do mercado de trabalho, $e$ as responsabilidades do estado.

\section{Referências bibliográficas}

CAVAlLI, Alessandro. Prolonging youth in Italy: "being in no hurry". In CAvalli, A. and Galland, O. (ed.) Youth in Europe. London, Pinter, 1995.

CHERLIN, Andrew J., SCABINI, Eugenia and ROSSI, Giovanna. Still in the Nest: Delayed Home Leaving in Europe and the United States. Journal of Family Issues 18:6, Thousand Oaks-CA, Sage Publications, 1997.

COOK, Thomas D. and FURSTENBERG Jr., Frank. Explaining Aspects of the Transition to Adulthood in Italy, Sweden, Germany, and the United States: A Cross-Disciplinary, Case Synthesis Approach. ANNALS: AAPSS, 2002.

GENDA, Yuji. Youth Employment and Parasite Singles. Japan Labour Bulletin 39:3, 2000.

GolsCH, Katrin. Employment flexibility in Spain and its impact on transitions to adulthood. Work, employment and society 17:4, 2003.

HOLDSWORTH, Clare. Leaving Home in Britain and Spain. European Sociological Review 16:2, 2000.

and SOLDA, Mariana Irazoqui. First Housing Moves in Spain: An Analysis of Leaving Home and First Housing Acquisition. European Journal of Population 18:1-19, 2002.

JURADO GUERRERO, Teresa. Youth in Transition: Housing, employment, social policies and families in France and Spain. Aldershot, Hants, Ashgate, 2001.

KATSUMATA, Y. Have we really reached the western standard of retired income security? From the viewpoints of public and private pension schemes. ISSA research conference on Social Security in a Long Life Society, Antwerp, May 2003 (http://www.issa.int/pdf/anvers03/topic4/2katsumata.pdf).

KosUGI, Reiko. The Transition from School to Work in Japan: Understanding the Increase in Freeter and Jobless Youth. Japan Labor Review 1:1, 2004. 
Laços que prendem

LEHENY, David. Think Global, Fear Local: Sex, Violence and Anxiety in Contemporary Japan. Ithaca-NY, Cornell University Press, 2006.

LUNSING, Wim. "Parasite" and "Non-parasite" Singles: Japanese Journalists and Scholars Taking Positions. Social Science Japan Journal 6:2, 2003.

MINISTRY OF INTERNATIONAL AFFAIRS AND COMMUNICATION. Marriage and Divorce. 2007 (http://www.stat.go.jp/ english/data/handbook/c02cont.htm).

and MANTING, Dorien. Strategies of Nest-Leavers: "Settling down" versus Flexibility. European Sociological Review 10:2, 1994. and HOOIMEIJER, Pieter. Leaving home in the Netherlands: Timing and first housing. Journal of Housing and the Built Environment 17, 2002.

NEWMAN, Katherine. Declining Fortunes: the withering of the American dream. New York-NY, BasicBooks, 1993.

NEWMAN, Katherine and APTEKAR, Sofya. Sticking Around: Delayed Departure from the Parental Nest in Western Europe. In: DANZIGER, Sheldon and ROUSE, Cecilia (eds.) The Price of Independence. New York, Russell Sage Foundation, 2008.

NiLSSON, Karina and STRANDH, Mattias. Nest Leaving in Sweden: The Importance of Early Educational and Labor Market Careers. Journal of Marriage and the Family 61:4, 1999.

RAYMO, James M. Premarital Living Arrangements and the Transition to First Marriage in Japan. Journal of Marriage and the Family 65, 2003.

WestofF, Charles F. and FREJKA, Tomas. Religiousness and Fertility Among European Muslims. Population and Development Review 33:4, 2007. 